

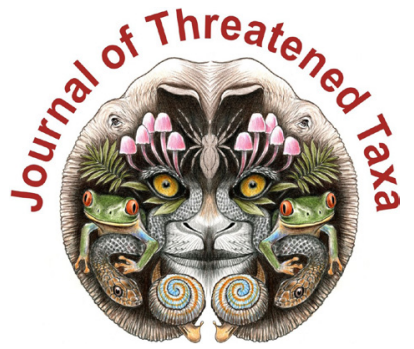

ISSN 0974-7907 (Online); ISSN $0974-7893$ (Print)

Publisher

Host

Wildlife Information Liaison Development Society

www.wild.zooreach.org

Zoo Outreach Organization www.zooreach.org

No. 12, Thiruvannamalai Nagar, Saravanampatti - Kalapatti Road, Saravanampatti, Coimbatore, Tamil Nadu 641035, India

Ph: +91 9385339863 | www.threatenedtaxa.org

Email: sanjay@threatenedtaxa.org

EDITORS

\section{Founder \& Chief Editor}

Dr. Sanjay Molur

Wildlife Information Liaison Development (WILD) Society \& Zoo Outreach Organization (ZOO),

12 Thiruvannamalai Nagar, Saravanampatti, Coimbatore, Tamil Nadu 641035, India

\section{Deputy Chief Editor}

Dr. Neelesh Dahanukar

Noida, Uttar Pradesh, India

\section{Managing Editor}

Mr. B. Ravichandran, WILD/ZOO, Coimbatore, India

\section{Associate Editors}

Dr. Mandar Paingankar, Government Science College Gadchiroli, Maharashtra 442605, India

Dr. Ulrike Streicher, Wildlife Veterinarian, Eugene, Oregon, USA

Ms. Priyanka Iyer, ZOO/WILD, Coimbatore, Tamil Nadu 641035, India

Dr. B.A. Daniel, ZOO/WILD, Coimbatore, Tamil Nadu 641035, India

\section{Editorial Board}

Dr. Russel Mittermeier

Executive Vice Chair, Conservation International, Arlington, Virginia 22202, USA

\section{Prof. Mewa Singh Ph.D., FASc, FNA, FNASc, FNAPsy}

Ramanna Fellow and Life-Long Distinguished Professor, Biopsychology Laboratory, and Institute of Excellence, University of Mysore, Mysuru, Karnataka 570006, India; Honorary Professor, Jawaharlal Nehru Centre for Advanced Scientific Research, Bangalore; and Adjunct Professor, National Institute of Advanced Studies, Bangalore

\section{Stephen D. Nash}

Scientific Illustrator, Conservation International, Dept. of Anatomical Sciences, Health Sciences Center, T-8, Room 045, Stony Brook University, Stony Brook, NY 11794-8081, USA

\section{Dr. Fred Pluthero}

Toronto, Canada

\section{Dr. Priya Davidar}

Sigur Nature Trust, Chadapatti, Mavinhalla PO, Nilgiris, Tamil Nadu 643223, India

\section{Dr. Martin Fisher}

Senior Associate Professor, Battcock Centre for Experimental Astrophysics, Cavendish

Laboratory, JJ Thomson Avenue, Cambridge CB3 OHE, UK

\section{Dr. John Fellowes}

Honorary Assistant Professor, The Kadoorie Institute, 8/F, T.T. Tsui Building, The University of Hong Kong, Pokfulam Road, Hong Kong

\section{Prof. Dr. Mirco Solé}

Universidade Estadual de Santa Cruz, Departamento de Ciências Biológicas, Vice-coordenado do Programa de Pós-Graduação em Zoologia, Rodovia Ilhéus/Itabuna, Km 16 (45662-000)

Salobrinho, Ilhéus - Bahia - Brasil

\section{Dr. Rajeev Raghavan}

Professor of Taxonomy, Kerala University of Fisheries \& Ocean Studies, Kochi, Kerala, India

\section{English Editors}

Mrs. Mira Bhojwani, Pune, India

Dr. Fred Pluthero, Toronto, Canad

Mr. P. Ilangovan, Chennai, India

Web Development

Mrs. Latha G. Ravikumar, ZOO/WILD, Coimbatore, India

\section{Typesetting}

Mr. Arul Jagadish, ZOO, Coimbatore, India

Mrs. Radhika, ZOO, Coimbatore, India

Mrs. Geetha, ZOO, Coimbatore India
Fundraising/Communications

Mrs. Payal B. Molur, Coimbatore, India

Subject Editors 2018-2020

Fungi

Dr. B. Shivaraju, Bengaluru, Karnataka, India

Dr. R.K. Verma, Tropical Forest Research Institute, Jabalpur, India

Dr. Vatsavaya S. Raju, Kakatiay University, Warangal, Andhra Pradesh, India

Dr. M. Krishnappa, Jnana Sahyadri, Kuvempu University, Shimoga, Karnataka, India

Dr. K.R. Sridhar, Mangalore University, Mangalagangotri, Mangalore, Karnataka, India

Dr. Gunjan Biswas, Vidyasagar University, Midnapore, West Bengal, India

\section{Plants}

Dr. G.P. Sinha, Botanical Survey of India, Allahabad, India

Dr. N.P. Balakrishnan, Ret. Joint Director, BSI, Coimbatore, India

Dr. Shonil Bhagwat, Open University and University of Oxford, UK

Prof. D.J. Bhat, Retd. Professor, Goa University, Goa, India

Dr. Ferdinando Boero, Università del Salento, Lecce, Italy

Dr. Dale R. Calder, Royal Ontaro Museum, Toronto, Ontario, Canada

Dr. Cleofas Cervancia, Univ. of Philippines Los Baños College Laguna, Philippines

Dr. F.B. Vincent Florens, University of Mauritius, Mauritius

Dr. Merlin Franco, Curtin University, Malaysia

Dr. V. Irudayaraj, St. Xavier's College, Palayamkottai, Tamil Nadu, India

Dr. B.S. Kholia, Botanical Survey of India, Gangtok, Sikkim, India

Dr. Pankaj Kumar, Kadoorie Farm and Botanic Garden Corporation, Hong Kong S.A.R., China

Dr. V. Sampath Kumar, Botanical Survey of India, Howrah, West Bengal, India

Dr. A.J. Solomon Raju, Andhra University, Visakhapatnam, India

Dr. Vijayasankar Raman, University of Mississippi, USA

Dr. B. Ravi Prasad Rao, Sri Krishnadevaraya University, Anantpur, India

Dr. K. Ravikumar, FRLHT, Bengaluru, Karnataka, India

Dr. Aparna Watve, Pune, Maharashtra, India

Dr. Qiang Liu, Xishuangbanna Tropical Botanical Garden, Yunnan, China

Dr. Noor Azhar Mohamed Shazili, Universiti Malaysia Terengganu, Kuala Terengganu, Malaysia

Dr. M.K. Vasudeva Rao, Shiv Ranjani Housing Society, Pune, Maharashtra, India

Prof. A.J. Solomon Raju, Andhra University, Visakhapatnam, India

Dr. Mandar Datar, Agharkar Research Institute, Pune, Maharashtra, India

Dr. M.K. Janarthanam, Goa University, Goa, India

Dr. K. Karthigeyan, Botanical Survey of India, India

Dr. Errol Vela, University of Montpellier, Montpellier, France

Dr. P. Lakshminarasimhan, Botanical Survey of India, Howrah, India

Dr. Larry R. Noblick, Montgomery Botanical Center, Miami, USA

Dr. K. Haridasan, Pallavur, Palakkad District, Kerala, India

Dr. Analinda Manila-Fajard, University of the Philippines Los Banos, Laguna, Philippines

Dr. P.A. Sinu, Central University of Kerala, Kasaragod, Kerala, India

Dr. Afroz Alam, Banasthali Vidyapith (accredited A grade by NAAC), Rajasthan, India

Dr. K.P. Rajesh, Zamorin's Guruvayurappan College, GA College PO, Kozhikode, Kerala, India

Dr. David E. Boufford, Harvard University Herbaria, Cambridge, MA 02138-2020, USA

Dr. Ritesh Kumar Choudhary, Agharkar Research Institute, Pune, Maharashtra, India

Dr. Navendu Page, Wildlife Institute of India, Chandrabani, Dehradun, Uttarakhand, India

\section{Invertebrates}

Dr. R.K. Avasthi, Rohtak University, Haryana, India

Dr. D.B. Bastawade, Maharashtra, India

Dr. Partha Pratim Bhattacharjee, Tripura University, Suryamaninagar, India

Dr. Kailash Chandra, Zoological Survey of India, Jabalpur, Madhya Pradesh, India

Dr. Ansie Dippenaar-Schoeman, University of Pretoria, Queenswood, South Africa

Dr. Rory Dow, National Museum of natural History Naturalis, The Netherlands

Dr. Brian Fisher, California Academy of Sciences, USA

Dr. Richard Gallon, llandudno, North Wales, LL30 1UP

Dr. Hemant V. Ghate, Modern College, Pune, India

Dr. M. Monwar Hossain, Jahangirnagar University, Dhaka, Bangladesh

Mr. Jatishwor Singh Irungbam, Biology Centre CAS, Branišovská, Czech Republic.

Dr. Ian J. Kitching, Natural History Museum, Cromwell Road, UK

Dr. George Mathew, Kerala Forest Research Institute, Peechi, India

For Focus, Scope, Aims, and Policies, visit https://threatenedtaxa.org/index.php/JoTT/aims_scope
For Article Submission Guidelines, visit https://threatenedtaxa.org/index.php/JoTT/about/submissions
For Policies against Scientific Misconduct, visit https://threatenedtaxa.org/index.php/JoTT/policies_various

continued on the back inside cover 


\title{
Seasonal food preferences and group activity pattern of Blackbuck Antilope cervicapra (L., 1758) (Mammalia: Cetartiodactyla: Bovidae) in a semi-arid region of western Haryana, India
}

\author{
Vikram Delu ${ }^{1}$ (D), Dharambir Singh ${ }^{2}$ (D), Sumit Dookia ${ }^{3}$ (D), Priya ${ }^{4}$ (D) \& Kiran ${ }^{5}$ (D) \\ 1,2,4,5 Department of Zoology and Aquaculture, Chaudhary Charan Singh Haryana Agricultural University Hisar, Haryana 125004, India. \\ ${ }^{3}$ University School of Environment Management, Guru Gobind Singh Indraprastha University, New Delhi 110078, India. \\ ${ }^{1}$ vikramdelu29@hau.ac.in (corresponding author), ${ }^{2}$ dharambir.titu@gmail.com, ${ }^{3}$ sumitdookia@gmail.com, ${ }^{4}$ priya@hau.ac.in, \\ ${ }^{5}$ kiranyodha3@gmail.com
}

\begin{abstract}
To evaluate food preferences and group activity patterns, a fragmented population of Blackbuck Antilope cervicapra was selected for observation in a semi-arid ecosystem of western Haryana. A field survey was conducted fortnightly, from dawn to dusk, between September 2019 and August 2020, covering every season. Scan sampling and quadrat methods were used to record data on group size and vegetation. Group sizes ranged from 3 to 72 individuals. Based on visual observation, blackbuck seasonally consumed 26 species belonging to 25 families with varied preferences, out of a total of 53 plant species documented from the study site. Some plant species with high medicinal and therapeutic values were preferred, including Artemisia scoparia, Cucumis callous, Ziziphus jujuba, and Ziziphus nummularia. Unlike most herbivores, Blackbuck also consumed the toxic and medicinally rich Calotropis procera. We suggest that zoos which house blackbuck include these preferred wild plant species in their diet. Observations on group activity were analyzed on hourly, monthly and seasonal bases, and converted into time percentages. Group foraging activity was at a maximum in the monsoon $(62 \%)$ and minimum in winter (50\%), followed by resting: maximum in winter $(21 \%)$ and minimum $(12 \%)$ in monsoon, largely influenced by food availability. Foraging/walking ratio was at a maximum (5.2) in monsoon and minimum (3.1) in winter, and was correlated with the number of group sightings (maximum in winter and minimum in monsoon) in nearby farmland, when the animals faced food scarcity in their natural habitat and fed on crops.
\end{abstract}

Keywords: Farmland, foraging activity, herbivores, medicinal, monsoon, natural habitat, observation, population, scarcity, vegetation.

Editor: David Mallon, Manchester Metropolitan University, UK.

Date of publication: 26 November 2021 (online \& print)

Citation: Delu, V., D. Singh, S. Dookia, Priya \& Kiran (2021). Seasonal food preferences and group activity pattern of Blackbuck Antilope cervicapra (L., 1758) (Mammalia: Cetartiodactyla: Bovidae) in a semi-arid region of western Haryana, India. Journal of Threatened Taxa 13(13): 19937-19947. https://doi.org/10.11609/ jott.7086.13.13.19937-19947

Copyright: (c) Delu et al. 2021. Creative Commons Attribution 4.0 International License. JoTT allows unrestricted use, reproduction, and distribution of this article in any medium by providing adequate credit to the author(s) and the source of publication.

Funding: None.

Competing interests: The authors declare no competing interests.

Author details, Author contributions and Hindi abstract: See end of this article.

Acknowledgements: VD, DS, and Priya (authors) are highly thankful for the kind support and financial assistance provided by the Department of Zoology and Aquaculture, CCS Haryana Agricultural University Hisar, Haryana. The contribution of forest officials of Fatehabad district, the personal of police department for the security in habitat has been counted worthy. We are also very grateful to Harikesh Saharan, PhD Scholar, Department of Botany, Kurukshetra University, Kurukshetra for helping in identifying the plant species in the habitat. VD would like to offer his sincere thanks to Dr. Sushma Bisht, senior scientific assistant, HARSAC for designing the study site map in GIS format. While all authors including SD would like to extend special thanks to Vinod Karwasra, the Haryana state president, Akhil Bhartitya Bishnoi Jeev Rakshya Sabha (ABBJRS) and all local stakeholders around the study site for their kindly support and guidance during the whole survey period.
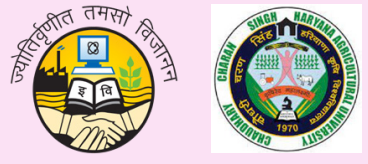


\section{INTRODUCTION}

The Blackbuck Antilope cervicapra (Linnaeus, 1758) is endemic to the Indian subcontinent. The adult male (subspecies rajputanae) weighs 34 to $45 \mathrm{~kg}$, while females weigh 31 to $39 \mathrm{~kg}$ (Ranjitsinh 1989). This antelope shows sexual dimorphism even at the age of 4-6 months when horns start growing in males; at maturity males become conspicuously colored and have long horns (Shrestha 2003). The coats of adult males are striking black or dark brown with white underparts, while the coat of females and immature males varies from tan to darker brown. Blackbucks live in open habitats such as grasslands, bush, and dry thorn scrub (Schaller 1967). The species was once distributed throughout western Pakistan from the foothills of the Himalaya from Punjab through Uttar Pradesh in India to the Terai zone of Nepal, West Bengal (India) to Bangladesh (Lydekker 1924). It is currently listed as Least Concern (LC) on the IUCN Red List (IUCN SSC Antelope Specialist Group 2017), but earlier it was categorized as Near Threatened (NT) (Mallon 2008). It is listed in Appendix III in CITES (Convention on International Trade in Endangered Species of Wild Fauna and Flora), and as a Schedule I species with highest protection level in India under the Indian Wildlife (Protection) Act, 1972. The recent improvement in the conservation status of Blackbuck is probably due to unintentional creation of more suitable open habitat by converting dense scrub land and woodland to agricultural areas (IUCN SSC Antelope Specialist Group 2017).

Various ecological and behavioural aspects of Blackbuck have been studied in India (Gupta \& Bhardwaj 1990; Gehlot \& Jakher 2007, 2011; Kumar \& Rahmani 2008; Dookia et al. 2011; Gangotri \& Gangotri 2014; Baskaran et al. 2016; Prashanth et al. 2016; Debata 2017; Sagar \& Antony 2017) and also in Khairapur, Bardia District, Nepal (Pradhan et al. 1999; DNPWC 2012). In Haryana, Ranjitsinh (1989) reported 2,410 Blackbuck from Hisar district alone, from a total of 4,852 Blackbuck in the state, making Hisar a high-density blackbuck area. So far, no detailed account of its foraging behavior has been documented in western Haryana.

The human population explosion, large-scale poaching, destruction of natural habitats for commercial cultivation, grazing activities and human habitation have caused Blackbuck to disappear from many areas. The total population is estimated at 35,000 mature individuals by IUCN (2017). Our primary census survey revealed that the isolated Blackbuck populations in Fatehabad, Hisar are in close proximity to villages dominated by the Bishnoi community, and in some parts of southern Haryana Blackbuck share their habitat with Nilgai Boselaphus tragocamelus. The main threats are habitat destruction, barbed wire fencing, feral dogs, and illegal hunting.

Blackbucks are mainly diurnal, but sometimes also active at night (Long 2003). They are gregarious (Schaller 1967) and mostly live in groups of single or mixed sexes numbering from 15 to several thousand animals. Densities are 0.5-3 per ha (Long 2003). Their diet includes grass, cereal crops and forbs, and they also browse on bushes (Long 2003). Blackbuck is reported as a crop pest in many habitats, where it eats mainly the young shoots of cereal and pulses, in particular sorghum and millet (Chauhan \& Singh 1990).

Seasonal or interannual variation in availability of resources suggests the presence of behavioral, physiological and morphological adaptations in consumers (Van Schaik et al. 1993) and may influence the composition of vertebrate faunal communities (Fleming et al. 1987). Furthermore, certain species of plants provide alternative food sources during times of food scarcity, and thus may be vital for population survival (Terborgh 1983). Group sizes increase with habitat openness and resource availability. This information can be helpful to assess the habitat requirements of animals, predict their presence or abundance in other areas and the potential effects of habitat transformation (Arthur et al. 1996; Ri'os-Uzeda et al. 2006), and to support wildlife management plans (Morrison et al. 2006).

The present study was carried out to characterize blackbuck habitats, activity patterns and resource usage in a patch of natural vegetation in a human-dominated landscape outside the protected area network in the semi-arid region of western Haryana. This information will guide long-term conservation of the state animal of Haryana.

\section{DESCRIPTION OF STUdY AREA}

The study site is situated in Badopal village of Fatehabad district, commonly called 'Blackbuck habitat Badopal' in the Western part of the state Haryana of India (29.418N, 75.576'E). The surrounding villages including Badopal are dominated by the Bishnoi community which has high reverence and tolerance towards blackbuck. Total area of study site is approximately $2.41 \mathrm{~km}^{2}$ including the area acquired by government to build a residential colony. The rest of the land is owned by local farmers. The study also extended further into the surrounding area of habitat under cultivation of different seasonal crops. 


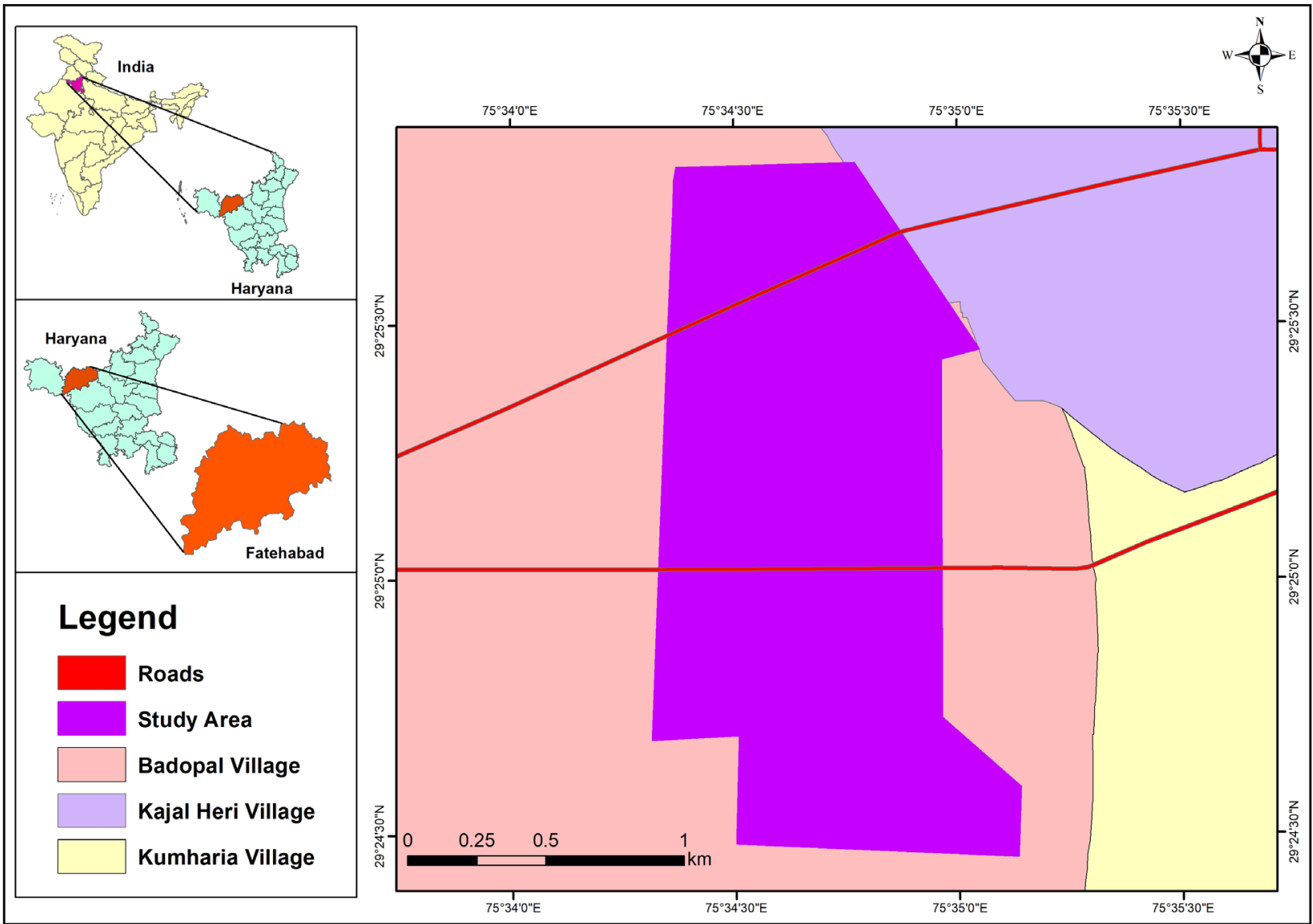

Figure 1. Study site map in Badopal village of Fatehabad district, Haryana, India.

\section{HISTORICAL BACKGROUND (BLACKBUCK HABITAT BADOPAL)}

The study site was selected in 2012 by Nuclear Power Corporation Limited (NPCIL) for construction of a residential colony on 183 acres $\left(0.76 \mathrm{~km}^{2}\right)$ of private and Panchyat land near Badopal village of District Fatehabad. The site was enclosed with blade wire fencing, resulting in the death of several blackbuck. This situation met strong resistance and criticism by locals from Bishnoi communities along with other wildlife organizations, and a case was filed with the National Green Tribunal (NGT) which resulted in no further infrastructure being built by NPCIL. The site is now governed and managed by the district administration, and the blackbuck habitat is still in need of the development of a conservation plan by the state government. Wildlife Institute of India (2015) did a reconnaissance and recommended this area, including adjoining private land, as a community reserve for conservation of blackbuck.

The study area lies in biogeographic province 4-A, Semi-arid, Punjab Plains (Rodgers et al. 2000), and the 'Trans-Gangetic Plains Regions' agroclimatic zone under the 'Arid to Semi-arid' climatic region, which is characterized by scanty rainfall, aridity and extremes of temperature. The vegetation comprises predominantly xerophytes and is characterized as 'tropical desert thorn'. This site is a natural patch surrounded by a semi-arid agro-ecosystem. Adjoining fields are used for growing crops such as wheat, maize, other cereals, cotton, and pulses. Apart from Blackbuck, the habitat also supports Nilgai, Desert Fox Vulpes vulpes pusilla, Asian Palm Civet Paradoxurus hermaphrodites, Indian Hedgehog Paraechinus micropus. Important reptiles include Monitor Lizard Varanu ssp., Indian Cobra Naja naja.

\section{METHODOLOGY AND MATERIALS}

\section{Blackbuck group activity patterns}

There are four seasons: monsoon (June to August), autumn (September to November), winter (December to February), and summer (March to May). Field observations were made from dawn to dusk from September 2019 to August 2020. Field visits were 
conducted fortnightly during each season to record the behavior and feeding preferences of Blackbuck. Except winter, the observations were taken during three diurnal phases: morning (0630-1000 h), noon (1200-1400 h), and evening (1600-1900 h). There was a slight change in timing during winter to 0800-1100 h, 1300-1500 h, and $1600-1830 \mathrm{~h}$ in morning, afternoon, and evening, respectively. Group activity patterns were recorded using the scan sampling method (Altman 1974). The sampling time was 15 minutes continuously with a sampling interval of 10 minutes. The observations recorded for the group activity were analyzed on hourly, monthly, and seasonal basis.

Number of animals engaged in a particular activity in a sample $\%$ Activity of group $=-\times 100$ Total number of animal engaged in all activities in a sample

The group activities were categorized as foraging, walking, resting, scanning/standing, social activities (playing, fight display, sexual activities, and grooming) and other activities (urination, defecation, marking, ear threat, and object aggression).

We calculated annual error mean squares (percentage time) and error degree of freedom applying Duncan Multiple Range Test (DMRT) using SPSS version 21.0 considering season(s) as replication and group activities as treatments.

\section{Vegetation sampling and food preferences}

Vegetation composition was recorded by randomly sampling 10 quadrats of $20 \times 20 \mathrm{~m}$. The tree composition of each quadrat was counted whereas shrubs and herbs were counted within sub-quadrates of $5 \times 5 \mathrm{~m}$ and $1 \times 1 \mathrm{~m}$ respectively. The density (D) of the flora was analyzed following Phillips (1959) and Mishra (1968).

Foraging activity was observed using binoculars. After each feeding bout and once the animals moved, the plant species eaten by the group were recorded. Diet preferences were also recorded by calculating the number of attempts by the animals to consume a particular plant species in a particular season. For this purpose we used quadrat sampling for the area left and right of a line transect.

Note: Guidelines issued by the Ministry of Health and Family Welfare, Government of India to combat COVID-19 were strictly followed during field visits during the lockdown period.

\section{Optical equipment}

A Nikon COOLPIX P900 digital camera and Nikon ACULON binoculars $\left(8 \times 42,8^{\circ}\right)$ were used for photography and taking observations from long distances so as not to disturb the normal activity of the animals.

\section{RESULTS}

\section{Floral Composition}

Plant species documented from the study site included 14 trees, five shrubs, 31 herbs, and three climbers. Among the trees, maximum density was demonstrated by Acacia senegal (200 individuals/ ha) followed by Melia azedarach (27.5 individuals/ ha). Density of dominant shrubs, herbs and climbers were: Parthenium hysterophorus (6170 individuals/ha), Artemisia scoparia $(13,200$ individuals/ha), and Citrullus colocynthis (702.5 individuals/ha).

\section{Frequency class distribution}

Frequency class distribution of different plant species is shown in Figure 2.

Out of 53 plant species identified in the habitat, it was observed that blackbuck largely prefer 26 , as shown in Table 1.

Blackbuck browsing on trees varies according to season, with a maximum in summer and winter. The preference for trees depends mainly on the availability and height of the tree. Data suggests that the preferred parts of Acacia senegal and Prosopis cineraria were leaves, whereas in case of Prosopis juliflora and Ziziphus jujuba, leaves, pods and fruits were preferred. Prosopis juliflora was ignored during the monsoon season due to availability of preferred food in ample quantity.

Only three species of shrub were eaten by Blackbuck: Calotropis procera, Maytenuse marginata, Ziziphus nummularia. The literature available so far on blackbuck has not reported Calotropis procera as a forage species, but our field investigation revealed that in summer and winter preferences for Calotropis were medium and high respectively, and low in monsoon and autumn. Blackbuck mainly feeds on the leaves of this species during scarcity of other food.

A total of 18 species of herb were mainly foraged on by the blackbucks especially in the monsoon and autumn season (Table 1), Grasses like Cynodon dactylon, Eragrostis spp., Dactylocteniuma egyptium, Digera muricata, Digitaria spp., Cyperus rotundus were preferred in every season. Aerva javanica and Artemisia scoparia are dominant herbs but consumed only when the preferred grasses are not available especially in autumn and to some extent in winter.

Most herbs were dominant in monsoon and autumn season but either become dry or unfavorable for 
Table 1. Food preferences of Blackbuck during different season: M-Monsoon | S-Summer, Au-Autumn | W-Winter | LP-Low Preference | MP-Medium Preference | HP-High Preference | NR-Not reported in that season | L-Leaves | SM-Stem | F-Fruits | P-Pods | WPWhole Plant |*-Non native.

\begin{tabular}{|c|c|c|c|c|c|c|c|c|}
\hline & \multirow{2}{*}{ Name of the plant } & \multirow[b]{2}{*}{ Family } & \multirow{2}{*}{$\begin{array}{l}\text { Majoring in the } \\
\text { season (mainly } \\
\text { vegetative phase) }\end{array}$} & \multicolumn{4}{|c|}{ Seasonal food preference } & \multirow{2}{*}{$\begin{array}{l}\text { Parts } \\
\text { eaten }\end{array}$} \\
\hline & & & & M & $\mathrm{Au}$ & W & S & \\
\hline A. & \multicolumn{8}{|l|}{ Trees } \\
\hline 1 & Acacia senegal & Mimosaceae & All & LP & LP & HP & HP & L \\
\hline 2 & Prosopis cineraria & Mimosaceae & All & LP & LP & MP & MP & L \\
\hline 3 & Prosopis juliflora * & Fabaceae & All & NR & LP & MP & $\mathrm{HP}$ & $L \& P$ \\
\hline 4 & Ziziphus jujuba & Rhamnaceae & All & LP & NR & NR & MP & $\mathrm{F}$ \\
\hline B. & \multicolumn{8}{|l|}{ Shrubs } \\
\hline 5 & Calotropis procera & Asclepiadaceae & All & LP & LP & HP & MP & L \\
\hline 6 & Maytenuse emarginata & Celastraceae & All & NR & LP & LP & MP & L \\
\hline 7 & Ziziphus nummularia & Rhamnaceae & All & MP & MP & HP & HP & $L \& F$ \\
\hline C. & \multicolumn{8}{|l|}{ Herbs } \\
\hline 8 & Aerva javanica & Amaranthaceae & $\mathrm{Au}$ & NR & LP & NR & NR & L \\
\hline 9 & Artemisia scoparia * & Asteraceae & $M \& A u$ & MP & MP & LP & NR & L\&S \\
\hline 10 & Boerhavia diffusa & Nyctaginaceae & M & LP & LP & NR & NR & L \\
\hline 11 & Cynodon dactylon & Poaceae & $\mathrm{S}, \mathrm{M}, \mathrm{Au}$ & $\mathrm{HP}$ & HP & NR & $\mathrm{HP}$ & WP \\
\hline 12 & Cyperus rotundus & Cyperaceae & $M \& A u$ & HP & HP & NR & NR & WP \\
\hline 13 & Dactyloctenium aegyptium * & Poaceae & $\mathrm{Au}$ & LP & MP & NR & NR & WP \\
\hline 14 & Digera muricata & Amaranthaceae & M & LP & LP & NR & NR & WP \\
\hline 15 & Digitaria spp. & Poaceae & M & MP & LP & NR & NR & WP \\
\hline 16 & Eragrostis spp. & Poaceae & $\mathrm{Au}$ & LP & MP & NR & NR & WP \\
\hline 17 & Euphorbia prostrata* & Euphorbiaceae & M & LP & MP & NR & NR & WP \\
\hline 18 & Indigofera linnaei & Fabaceae & M & LP & NR & NR & NR & WP \\
\hline 19 & Heliotropium europaeum & Boraginaceae & $\mathrm{Au}$ & NR & LP & NR & NR & WP \\
\hline 20 & Chenopodium album & Chenopodiaceae & $\mathrm{M}$ and $\mathrm{Au}$ & LP & LP & NR & NR & WP \\
\hline 21 & Pupalia lappacea & Amaranthaceae & $\mathrm{Au}$ & LP & LP & NR & NR & SM \& L \\
\hline 22 & Setaria virdis & Poaceae & $M \& S$ & MP & MP & NR & NR & WP \\
\hline 23 & Tephrosia purpurea & Fabaceae & $M \& A u$ & LP & MP & NR & NR & $L \& P$ \\
\hline 24 & Trianthema portulacastrum & Aizoaceae & M & MP & LP & NR & NR & WP \\
\hline 25 & Xanthium strumarium * & Asteraceae & $M \& A u$ & LP & LP & NR & NR & WP \\
\hline D. & \multicolumn{8}{|l|}{ Climbers } \\
\hline 26 & Cucumis callosus & Cucurbitaceae & $S \& M$ & LP & LP & NR & MP & $\mathrm{F}$ \\
\hline
\end{tabular}

feeding during winter and summer (Table 2). Many plant species listed in Table 1 are also consumed by nilgai, so interspecific competition between Blackbuck and Nilgai may result in resource partitioning. Crop raiding increases during winter and summer seasons (Table 3).

\section{Group activity pattern}

Seasonal variations in group activity of the blackbuck were recorded (Figs. 3 and 4)

The annual data suggests that maximum time (62\%)

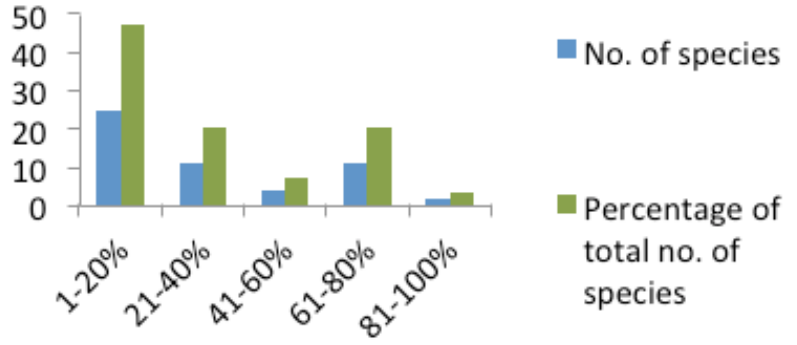

Figure 2. Frequency class distribution of plant species showing the number of species and percentage of the total number of the species. 


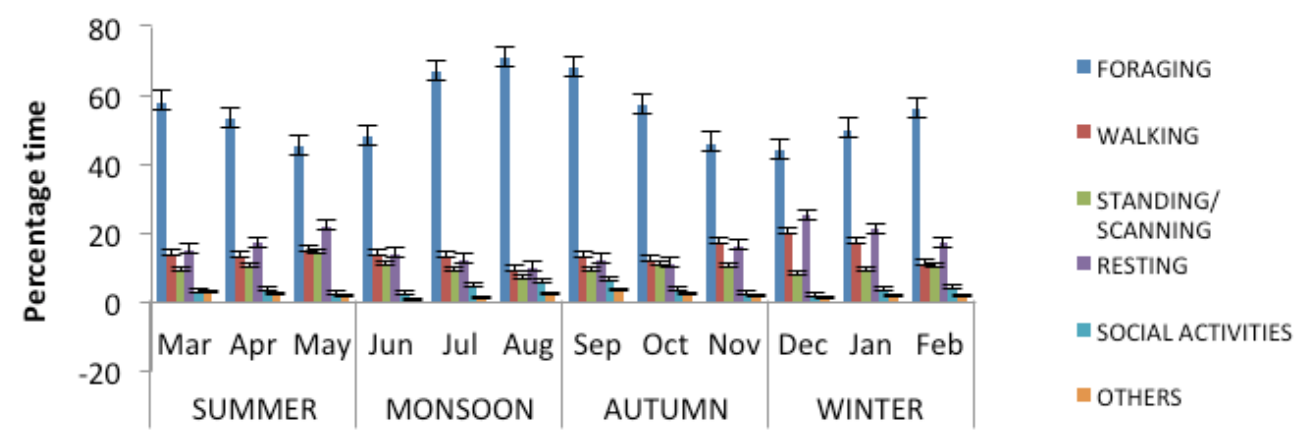

\section{Month wise group activity}

Figure 3. Percentage time versus monthly group activity by Blackbuck (Error bars with standard error).

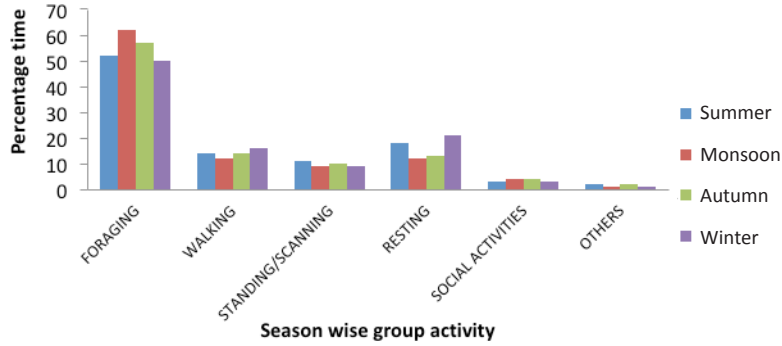

Figure 4. Percentage time spent on a particular group activity by season.

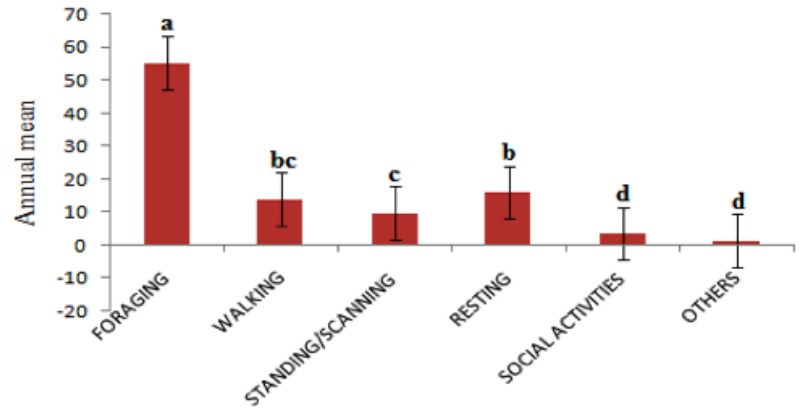

Figure 5. Annual mean of group activity (treatment bars with different letters differ significantly at $\boldsymbol{P} \leq \mathbf{0 . 0 5}$ based on Duncan Multiple Range Test.

Table 2. Most dominant vegetation during all seasons, except trees, in descending order, and their interactions with Blackbuck. Some plant species were dominant in two seasons with varying densities.

\begin{tabular}{|c|c|c|c|}
\hline \multicolumn{4}{|c|}{ Dominant flora covering the habitat in particular season } \\
\hline \multicolumn{4}{|l|}{ A. Monsoon } \\
\hline Scientific name & Category & $\begin{array}{c}\text { Food } \\
\text { preference }\end{array}$ & Remarks \\
\hline Artemisia scoparia & Herb & Yes & Low preference for food in monsoon \\
\hline Verbesina encelioides & Herb & No & $\begin{array}{l}\text { Full bloom make the landscape helpful during parturition of females but inhibits } \\
\text { communication and restrict establishment of territory by adult males and makes them } \\
\text { vulnerable to feral dogs attacks. }\end{array}$ \\
\hline Cyperus rotundus & Herb & Yes & One of the favorite diet items \\
\hline \multicolumn{4}{|l|}{ B. Autumn } \\
\hline Artemisia scoparia & Herb & Yes & Medium food preference in late autumn \\
\hline Verbesina encelioides & Herb & No & Drier in late autumn, no direct use; hindrance for territory establishment. \\
\hline Pupalia lappacea & Herb & Yes & Low preference, drier during late autumn, no use when completely dry. \\
\hline \multicolumn{4}{|l|}{ C. Winter } \\
\hline Pupalia lappacea & Herb & Yes & $\begin{array}{l}\text { The habitat was mostly covered with this herb in dry condition during extreme winter. } \\
\text { Low food preference in autumn and monsoon season. }\end{array}$ \\
\hline Verbesina encelioides & Herb & No & $2^{\text {nd }}$ most dominant in habitat, mostly dry and used for preorbital marking. \\
\hline Artemisia scoparia & Herb & Yes & Dried, preferred as a secondary food \\
\hline \multicolumn{4}{|l|}{ D. Summer } \\
\hline Verbesina encelioides & Herb & No & $\begin{array}{l}\text { High density during late summer, no direct use except to hide the infant by females during } \\
\text { initial days of nurturing }\end{array}$ \\
\hline Parthenium hysterophorus & Shrub & No & No direct use but advantageous for feral dogs for attacking blackbucks. \\
\hline
\end{tabular}


was spent for foraging activity during monsoon followed by autumn (57\%), summer (52\%), and winter (50\%) (Figure 4). Foraging activities were directly related to availability of food. Blackbuck spent more time resting in winter than in other seasons.

Diurnally, maximum number of crop raids (28 raids/ sighting) were observed in winter followed by summer (22 raids/sighting) and minimum (11 raids/sighting) in monsoon (Table 4). Public opinion around the study site revealed that the crop raids were more prominent at night than in daytime.

\section{The foraging to walking ratio}

The foraging to walking ratio is a very important factor to evaluate the foraging success and assessment of habitat in terms of food availability. The animals spent more time walking in winter and summer season during less availability of food. The foraging to walking ratios for monsoon and autumn were 5.16 and 4.07 respectively, higher than summer and winter ratios of 3.71 and 3.12, respectively.

It was observed that blackbuck group composition and population fluctuation are also affected by crop patterns in the region due to high nutritional value of agricultural crops. The recorded data indicates a strong relationship between the foraging walking ratio and crop raiding during different season (Table 3 ).

All the annual group activities were statistically significant $(p<0.05)$ except social and other activity. Foraging activity was maximum followed by resting, walking, standing/scanning (Figure 5). As per the recorded data, animal spent $>3.0$ times on foraging, fulfilling their food requirement to performing all other such activities.

\section{Conservation implications}

Based on our primary census survey, and the reconnaissance study of Wildlife Institute of India (2015) the Blackbuck populations in the districts of western Haryana are fragmented and distributed in small isolated patches surrounded by high human habitation and intensive agricultural practices. All these small size populations in villages like Mangali- Rawat Khera, Balsamand, (Hisar) Dhangar (Community Reserve for Blackbuck, 25 acres (2019)), Badopal (Current study site) (Fathehabad) harboring in same climatic semi-arid conditions and plant communities. Due to agricultural revolution and better irrigation system in Haryana, currently these sites have no true grasslands as preferred by the blackbucks, so the species have only options to feed on available plant species and consumed on crops
Table 3. Diurnal seasonal data of foraging walking ratio and group sighting in nearby agricultural lands.

\begin{tabular}{|l|c|c|}
\hline Season & $\begin{array}{l}\text { Foraging walking } \\
\text { ratio(within habitat) } \\
\text { (A) }\end{array}$ & $\begin{array}{l}\text { No. of group sighted } \\
\text { ranging from (3-38) in } \\
\text { adjoining agricultural } \\
\text { field in a radius of } \\
\mathbf{0 . 0 5 ~ k m ~ t o ~ 4 ~ k m ~ ( B ) ~}\end{array}$ \\
\hline Summer & 3.71 & 22 \\
\hline Monsoon & 5.16 & 11 \\
\hline Autumn & 4.07 & 15 \\
\hline Winter & 3.12 & 28 \\
\hline $\begin{array}{l}\text { Pearson Correlation } \\
\text { between (A) and (B) }\end{array}$ & $-0.947^{\text {NS }}$ & \\
\hline
\end{tabular}

to fulfill its nutritional demands. Therefore, the feeding pattern of the species has adapted according to the changing climatic and floral compositions during time and space.

\section{DISCUSSION}

Meeting nutritional demands is the most essential task for any animal (Parker et al. 2009). Challenges faced by ruminant herbivores are mainly linked to forage quality (Drent \& Prins 1987; Illius \& Gordon 1992), because green plants provide a relatively small yield of nutrients and require complicated mechanisms of fiber digestion based on microbial fermentation (Van Soest 1994). Selecting forage with high protein and low fiber content optimizes nutrient and energy intake and also reduces retention time, thus increasing intake capacity (Van Soest 1994; Mysterud et al. 2001). Additional selection criteria include the dietary need for essential minerals and secondary metabolites (Cassini 1994). Habitat use results from multiscale and multifactorial processes (Senft et al. 1987; Bailey et al. 1996; Van Beest et al. 2010) and its outcome in terms of individual movement and distribution depends on habitat use by multifactorial processes the outcome of which depended on the variations of landscapes of food in space and time (Mueller \& Fagan 2008).

Foraging patterns and food preferences of blackbuck have been studied in Rajasthan and southern India, but without relating feeding data to group activity patterns. Unlike chinkara Gazella bennettii, Blackbucks are not found in true deserts, but attain their highest densities in semi-arid grassland-scrub systems where they prefer short grasslands $(<50 \mathrm{~cm})$ and avoid wooded habitats and grasslands above shoulder height (Jhala 

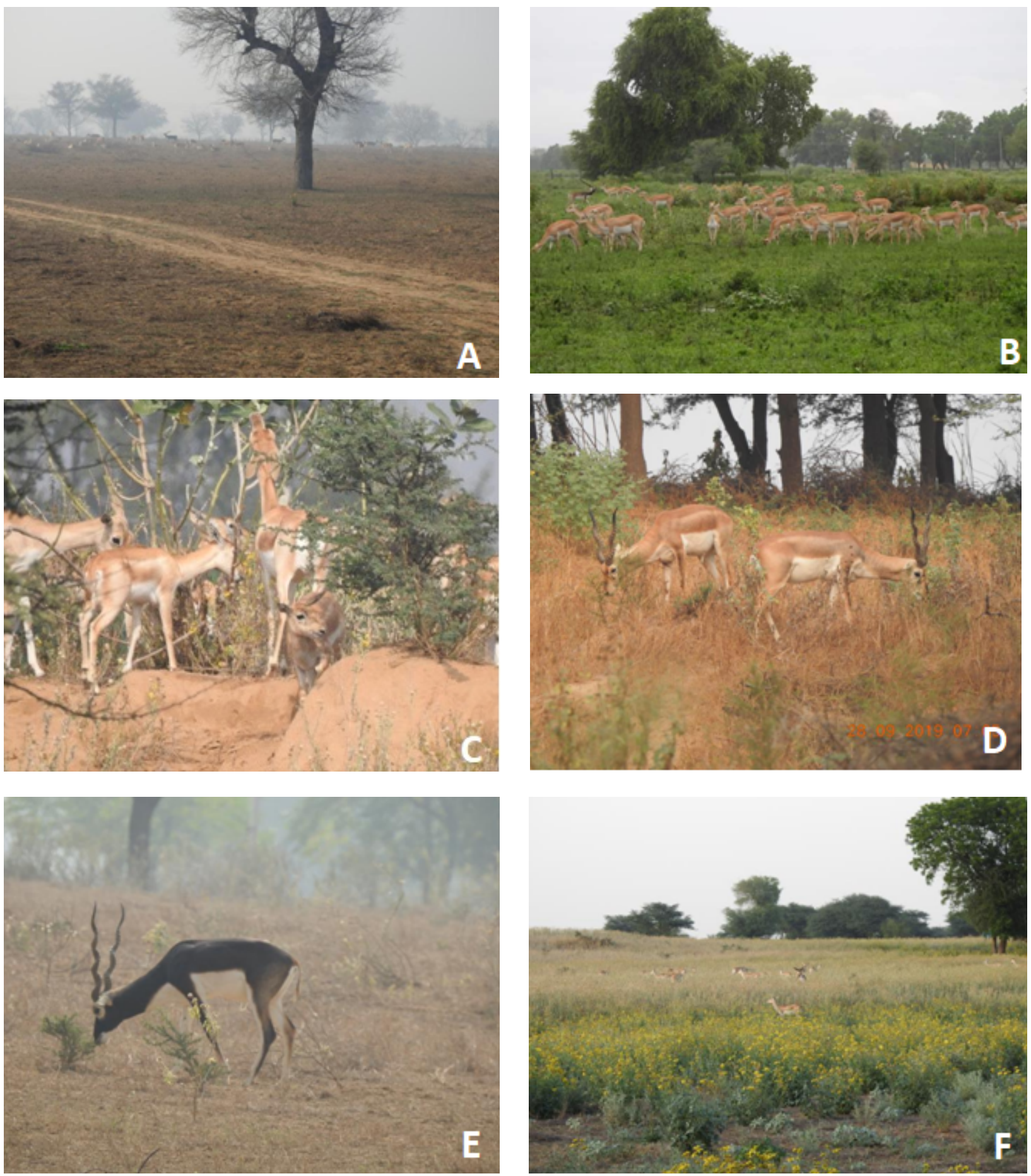

Image 1. A-Habitat view in February 2020 | B-Harem/family/mixed herd during monsoon season (July 2020) | C-Females foraging on Calotropis procera (late November 2019) | D-Two male blackbuck (age 2-3 years) nibbling on Artemisia scoparia (Autumn) | E-Adult male blackbuck browsing on Acacia senegal (late Autumn) | F-Habitat dominated with Verbesina encelioides in April 2020. () Vikram Delu.

1991). Their diet primarily consists of grasses so there is profound seasonality in their nutritional ecology. Pods and fallen leaves of trees such as Acacia species and Prosopis juliflora are favored in summer, and Dichanthium annulatum during monsoon season (Jadeja et al. 2013). Berseem Trifolium alexandrinum and oats Avena sativa are provided as food sources for blackbuck in captivity (Pathak et al. 1992). Foraging activity is at a minimum during summer, a little higher during winter and at a maximum during the monsoon season (Nair 
1975; Chattopadhyay \& Bhattacharya 1986; Kumar 1993). However, in this study foraging activity was slightly higher in summer than winter. Blackbucks have access to high quantity and quality forage during the monsoon (June-August) and early autumn (September) and in summer (March-April) coinciding with periods of maximum grass growth, the other months remain more or less dry to varying degrees.

Blackbucks are adapted to grassland ecosystems, and have evolved to conserve water by increasing the urea concentration in their urine and water reabsorption from their feces (Jhala et al. 1992). The protein content of the blackbuck diet drops significantly $(<4 \%)$ in summer, well below the maintenance requirement for ruminants which is 5.5-9\% (Robbins 1983). During this period, protein digestibility is negative, i.e., Blackbuck loses more protein via feces than they can obtain from the forage. The digestibility of dry matter declines from a high of $76.5 \%$ during the monsoon to a low of $32 \%$ during summer. Blackbuck adapt to this low-quality diet by reducing intake from over $130 \mathrm{~g} / \mathrm{kg} 0.75$ during the monsoon to less than $20 \mathrm{~g} / \mathrm{kg} 0.75$ during summer (Jhala 1997).

During the present investigation the animals showed selectivity in food choices from available food in the habitat. It was also noted that blackbuck feed on Calotropis procera which is generally not eaten by herbivores due to the high concentration of alkaloids.

The present study suggests that the level of selectivity of food is not fully related to the dominance of plant species in a particular season. For example, Verbesina encelioides, Parthenium hysterophorus dominated in summer and Verbesina encelioides was the second most dominant in the monsoon but these plants were not the preferred food items of blackbuck. Similar variations in the diet of the Blackbuck have been reported in northwestern, central, and southern India and in parts of Nepal (Jhala 1997; Mahato et al. 2010; Jhala \& Isvaran 2016).

Like most tropical ungulates, the body condition of Blackbuck cycles from good (during monsoon and autumn) to poor (during late summers and winter) due to the utilization of body fat and muscle proteins. To compensate their food requirements the animal shows physiological and behavioral adaptations by shifting to browsing instead of grazing and more crop raiding was reported during summer and winter. The feeding to walking ratio observed in the present study was higher in monsoon and autumn than in summer and winter and the number of crop raids were lower in monsoon and autumn than summer and winter. Our findings are supported by the observations of Hofmann (1989) that Blackbuck face a more prolonged period of low nutrition during hot summer and dry winter in comparison to other tropical ungulates studied in Africa as the dry spell in India lasts for over nine months as compared to 4-6 months in Africa. Blackbucks are unusual as they are relatively small (with correspondingly higher energy requirements) and have specialized on a low-quality forage source, i.e., grasses. A data set of the dietary preferences of mammalian species can be useful in elucidating a wide range of ecological processes, such as predator-prey interactions (Sinclair 2003; Jones \& Safi 2011) and eco-morphological diversification (Davies et al. 2007).

\section{CONCLUSION}

The food preferences and behavior of a species are determined by the biogeographic region, climatic factors, food availability, prey-predator base and interspecific competition. Blackbuck diets are influenced by all these parameters. The present study is first of its kind in western Haryana on dietary choice, seasonality of available food items and behavioral shift from grazing to browsing by Blackbucks and will assist development of a scientific conservation plan for the many fragmented population of this species in and around Haryana. We would like to suggest that zoos of India which hold Blackbuck should include these preferred wild plant species in Blackbuck diet. The present study also emphasizes to the district and state authorities to notify and conserve this habitat as a community reserve and to include participation by local people to strengthen community-based wildlife conservation in the area.

\section{REFERENCES}

Altmann, J. (1974). Observational study of behaviour: sampling methods. Behavior 49: 227-265. https://doi. org/10.1163/156853974X00534

Arthur, S.M., B.F.J. Manly, L.L. MacDonald \& G.W. Garner (1996). Assessing habitat selection when availability changes. Ecology 77: 215-227.

Bailey, D.W., E.G. John, A.L. Emilio, R.R. Larry, B.C. Michael, M.S. David \& L.S. Phillip (1996). Mechanisms that result in large herbivore grazing distribution patterns. Journal of Range Management 49: 386-400.

Baskaran, N., K. Ramkumaran \& G. Karthikeyan (2016). Spatial and dietary overlap between Blackbuck (Antilope cervicapra) and Feral Horse (Equus caballus) at Point Calimere Wildlife Sanctuary, southern India: competition between native versus introduced species. Mammalian Biology 81(3): 295-302. https://doi. org/10.1016/j.mambio.2016.02.004 
Bell, W.J. (1991). Searching Behaviour: The Behavioural Ecology of Finding Resources. Chapman and Hall Ltd, London, UK, 370 pp.

Bowyer, R.T. \& J.G. Kie (2006). Effects of scale on interpreting lifehistory characteristics of ungulates and carnivores. Diversity and Distributions 12: 244-257.

Büchi, L. \& S. Vuilleumier (2014). Coexistence of specialist and generalist species is shaped by dispersal and environmental factors. The American Naturalist 183: 612-624.

Cassini, M. (1994). Behavioral mechanisms of selection of die components and their ecological implications in herbivorous mammals. Journal of Mammalogy 75: 733-740.

Chattopadhay, B. \& T. Bhattacharya (1986). Basic diurnal activity pattern of blackbuck Antilope cervicapra Linn. of Ballavpur Wildlife Sanctuary, W.B. and its seasonal variation. Journal of the Bombay Natural History Society 83(3): 553-561.

Chauhan, N.P.S. \& R. Singh (1990). Crop Damage by Over abundant Populations of Nilgai and Blackbuck in Haryana (India) and its Management, pp. 218-220. Proceedings of the Fourteenth Vertebrate Pest Conference

Davies, T.J., S. Meiri, T.G. Barracloughand \& J.L. Gittleman (2007) Species co-existence and character divergence across carnivores. Ecology Letters 10: 146-152.

Debata, S. (2017). Population size, herd structure and sex ratio of the Blackbuck Antilope cervicapra (Mammalia: Cetartiodactyla: Bovidae) in a human dominated area in Odisha, India. Journal of Threatened Taxa 9(11): 10953-10955. https://doi.org/10.11609/ jott.2658.9.11.10953-10955

DNPWC (2012). Chitwan National Park (Booklet). Department of National Parks and Wildlife Conservation, Kathmandu, Nepal.

Dookia, S., S.K. Das, S.S. Poonia, G. Gupta \& Rajlakshmi (2011) Taal Chhapar Blackbuck Sanctuary, Rajasthan, India: a threatened ecosystem, pp. 70-77. In: Proceedings of the National Seminar on the Natural Resource Management and Environmental Issues, Govt. Lohia PG, College, Churu, Rajasthan, 170pp.

Dookia, S. \& G.R. Jakher (2007). Food and Feeding Habit of Indian Gazelle (Gazellabennettii), in the Thar Desert of Rajasthan. Indian Forester 133(10): 1327-1340.

Drent, R.H. \& H.H.T. Prins (1987). The herbivore as prisoner of its food supply, pp. 131-147. In: van Andel, J., J.P. Bakker \& R.W. Snaydon (eds.). Disturbance in Ggrasslands. Dr W. Junk Publishers, Dordrecht.

Eisenberg, J.F. (1981). The Mammalian Radiations: an Analysis of Trends in Evolution, Adaptation, and Behavior. University of Chicago Press, Chicago, Illinois, USA

Fleming, T.H., R. Breitwisch \& G.H. Whitesides (1987).Patterns of tropical vertebrate frugivore diversity. Annual Review of Ecology and Systematics 18: 91-109.

Gangotri, V.M. \& M.S. Gangotri (2014). Time-budget of different life history stages of the Blackbuck, Antilope cervicapra (Linnaeus), pp. 71-77. In: Advances in Biotechnology and Patenting. Elsevier Publication, New Delhi, $339 \mathrm{pp}$.

Gehlot, H.S. \& G.R. Jakher (2007). Distribution, status and conservation of Blackbuck Antilope cervicapra in Thar Desert of Rajasthan (India). Tigerpaper 34(4): 19-23

Gehlot, H.S. \& G.R. Jakher (2011). Habitat selection patterns of Blackbuck Antilope cervicapra and Chinkara Gazella bennetti in Thar Desert of Rajasthan (India). Tigerpaper 38(3): 17-23.

Gupta, R.C. \& C.S. Bhardwaj (1990). Seasonal changes in the herd structure and composition of Indian Blackbuck Antelope cervicapra at Pipli Deer Park in Kurukshetra District of Haryana State. Journal of Environmental Biology 11: 313-319.

Hofmann, R.R. (1989). Evolutionary steps of ecophysiological adaptation and diversification of ruminants: a comparative view of their digestive system. Oecologia 78: 443-457.

Illius, A.W. \& I.J. Gordon (1992). Modelling the nutritional ecology of ungulate herbivores: evolution of body size and competitive interactions. Oecologia 89: 428-434.

IUCN SSC Antelope Specialist Group (2017). Antilope cervicapra. The IUCN Red List of Threatened Species 2017:e. T1681A50181949. Downloaded on 10 September 2020. https://doi.
org/10.2305/IUCN.UK.20172.RLTS.T1681A50181949.en

Jadeja, S., S. Prasad, S. Quader \& K. Isvaran (2013). Antelope mating strategies facilitate invasion of grasslands by a woody weed. Oikos 122(10): 1441-1452.

Jhala Y.V., R.H. Giles Jr. \& A.M. Bhagwat (1992). Water in the ecophysiology of blackbuck. Journal of Arid Environments 22: 261269.

Jhala, Y.V. (1991). Habitat and population dynamics of wolves and blackbuck in Velavadar National Park, Gujarat, India. Dissertation. Virginia Polytechnic Institute and State University, Blacksburg

Jhala, Y.V. (1997). Seasonal effects on the nutritional ecology of blackbuck Antelope cervicapra. Journal of Applied Ecology 34: 1348-1358.

Jhala, Y.V. \& K. Isvaran (2016). Behavioural Ecology of a Grassland Antelope, the blackbuck Antilope cervicapra: Linking Habitat, Ecology and Behavior, pp. 151-176. In: Ahrestani, F.S. \& M. Sankaran (eds.). The Ecology of Large Herbivores in South and Southeast Asia. Springer Nature Publication, Dordrecht.

Jones, K.E. \& K. Safi (2011). Ecology and evolution of mammalian biodiversity. Philosophical Transactions of the Royal Society of London B 366: 2451-2461.

Jones, K.E., J. Bielby, M. Cardillo, S.A. Fritz, J. O’Dell \& C.D.L. Orme (2009). PanTHERIA: a species-level database of life history, ecology, and geography of extant and recently extinct mammals. Ecology 90: 2648.

Kissling, W.D., C. Rahbek \& K. Böhning-Gaese (2007). Food plant diversity as broad-scale determinant of avian frugivore richness. Proceedings of the Royal Society of London B: Biological Sciences 274: 799-808.

Kronfeld, N. \& T. Dayan (1998). A new method of determining diets of rodents. Journal of Mammalogy 79: 1198-1202.

Kubale, V. (2010). Taste Perception: From Anatomical To Molecular Level. Institute of Anatomy, Histology and Embryology, Veterinary Faculty, University in Ljubljana, Gerbičeva 60, SI-1115 Ljubljana, Slovenia. Slov Vet Res 47(3): 107-127.

Kumar, A. (1993). The ecology and behaviour of Blackbuck Antilope cervicapra, Ph.D. Thesis, M.D.S. University, Ajmer.

Kumar, S. \& A.R. Rahmani (2008). Predation by Wolves (Canis lupus pallipes) on Blackbuck (Antilope cervicapra) in the Great Indian Bustard Sanctuary, Nannaj, Maharashtra, India. International Journal of Ecology and Environmental Sciences 34(2): 99-112.

Lever, J.J., E.H. Van Nes, M. Scheffer \& J. Bascompte (2014). The sudden collapse of pollinator communities. Ecology Letters 17: 350-359.

Long, J.L. (2003). Introduced mammals of the world: their history, distribution and influence, CSIRO Publishing, Victoria, Australia, 486pp.

Lydekker, R. (1924). The Game Animals of India, Burma, Malaya and Tibet. Gyan Publishing House, London, 450pp.

Mahato, A.K. Roy, Ramakrishna \& M. Raziuddin (2010). Status, Ecology and Behaviour of Antilope cervicapra (Linnaeus, 1758) in Proposed Community Reserve for Blackbuck, Ganjam District, Orissa, India. Zoological Survey of India, Kolkata, 160pp.

Makin, D.F., C.J. Simon \& A.M. Shrader (2018). Changes in feeding behavior and patch use by herbivores in response to the introduction of a new predator. Journal of Mammalogy 99(2): 341-350. https:// doi.org/10.1093/jmammal/gyx17

Mallon, D.P. (2008). Antilope cervicapra. The IUCN Red List of Threatened Species 2008: e.T1681A6448761. Downloaded on 09.xi.2016. https://doi.org/10.2305/IUCN.UK.2008.RLTS. T1681A6448761.en

Mishra, R. (1968). Ecology Work-Book. Oxford and IBH Publishing Co., New Delhi, 242 pp.

Morrison, M.L., B.G. Marcot \& R.W. Mannan (2006). Wildlife Habitat Relationships, Concepts and Applications. Island Press, Washington, DC, USA, $493 \mathrm{pp}$.

Mougi, A. \& M. Kondoh (2012). Diversity of interaction types and ecological community stability. Science 337: 349-351.

Mueller, T. \& W.F. Fagan (2008).Search and navigation in dynamic 
environments - from individual behaviors to population distributions. Oikos 117: 654-664.

Mysterud, A., R. Langvatn, N.G. Yoccoz \& N.C. Stenseth (2001). Plant phenology, migration and geographical variation in body weight of a large herbivore: the effect of a variable topography. Journal of Animal Ecology 70: 915-923.

Nair, S.S. (1976). A population survey and observations on the behaviour of the blackbuck in the Point Calimere Sanctuary, Tami Nadu. Journal of the Bombay Natural History Society 73: 304-310.

Nowak, R.M. (1999). Walker's Mammals of the World, Volumes 1 and 2. Johns Hopkins University Press, Baltimore, Maryland, USA, 2015pp.

Parker, K.L., P.S. Barboza \& M.P. Gillingham (2009). Nutrition integrates environmental responses of animals. Functional Ecology 23: 57-69.

Pathak, N.N., N. Kewalramani \& D.N. Kamra (1992). Intake and digestibility of oats Avena sativa and berseem Trifolium alexandrinum in adult blackbuck Antilope cervicapra. Small Ruminant Research 8(3): 265-268.

Phillips, E.A. (1959). Methods of Vegetation Study. Henry Holt and Co., Inc, New York, 107 pp.

Pradhan, N.M., S.R. Bhatta, S.R. Jnawali \& S.R. Pathak (1999). Blackbuck Conservation Study Report. RBNP, Bardiya, Nepal (Script in Nepali).

Prashanth, M.B., A.M. Mathivanan \& T. Ganesh (2016). Conservation of a fragmented population of Blackbuck Antilope cervicapra. Current Science 3(3): 543-549.

Ranjitsinh, M.K. (1989). The Indian Blackbuck. Natraj Publishers, Dehradun, $155 \mathrm{pp}$.

Ri'os-Uzeda, B., H.Go' mez \& R.B.Wallace (2006). Habitat preferences of the Andean Bear (Tremarctus ornatus) in the Bolivian Andes. Journal of Zoology 268: 271-278.

Robbins, C.R. (1983). Wildlife Feeding and Nutrition. Academic Press, New York, $366 \mathrm{pp}$.

Rodgers, W.A., H.S. Panwar \& V.B. Mathur (2000). Wildlife Protected Area Network in India: A Review (Executive Summary). Wildlife Institute of India, Dehradun.

Sagar, H.S.S.C. \& P.U. Antoney (2017). Measuring Indian Blackbuck Antilope cervicapra (Mammalia: Cetartiodactyla: Bovidae) abundance at Basur Amruth Mahal Kaval Conservation Reserve, Chikkamagaluru, southern India. Journal of Threatened Taxa 9(7): 10468-10472. https://doi.org/10.11609/jott.2971.9.7.1046810472

Schaik, V.C.P., J.W. Terborgh \& S.J. Wright (1993). The phenology of tropical forests: adaptive significance and consequences for primary consumers. Annual Review of Ecology and Systematics 24: 353-377.

Schaller, G.B. (1967). The Deer and The Tiger. Chicago University Press, Chicago, USA, 384pp.

Senft, R.L., M.B. Coughenour, D.W. Bailey, L.R. Rittenhouse, O.E. Sala \& D.M. Swift (1987). Large herbivore foraging and ecological hierarchies. Bioscience 37: 789-799.

Shrestha, T.K. (2003). Wildlife of Nepal. Kathmandu, Nepal, 190 pp.

Sinclair, A.R. (2003). Mammal population regulation, keystone processes and ecosystem dynamics. Philosophical Transactions of the Royal Society of London B 358: 1729-1740.
Terborgh, J. (1983). Five New World Primates: A Study in Comparative Ecology. Princeton, New Jersey: Princeton University Press. Retrieved August 7, 2021, from http://www.jstor.org/stable/j. ctt7ztr6n

Ungar, P.S. (2010). Mammal Teeth: Origin, Evolution, and Diversity. Johns Hopkins University Press, Baltimore, Maryland, USA, 304 pp.

van Beest, F.M., M. Atle, E.L. Leif \& M.M. Jos (2010). Forage quantity, quality and depletion as scale-dependent mechanisms driving habitat selection of a large browsing herbivore. Journal of Animal Ecology 79: 910-922.

van Soest, P.J. (1994). Nutritional Ecology of the Ruminant. Cornell University Press, New York, 488 pp.

Wildlife Institute of India (2015). Blackbuck and its habitat in and adjoining landscape of NPCIL colony site., Badopal, Fathehabad, Haryana state. Reconnaissance survey report. WII Dehradun, 9-13pp.

Wilson, D.E. \& D.A.M. Reeder (2005). Mammal Species of the World: A Taxonomic and Geographic Reference. Johns Hopkins University Press, Baltimore, MD, $2142 \mathrm{pp}$.

Zweifel-Schielly, B., M. Kreuzer, K.C. Ewald \& W. Suter (2009). Habitat selection by an Alpine ungulate: the significance of forage characteristics varies with scale and season. Ecography 32: 103-113.

Hindi: कृष्ण मृग (एंटीलोप सर्विकाप्रा) की खाद्य वरीयताओं और समूह गतिविधि प्रतिरूप का मूल्यांकन करने के लिए, पश्चिमी हरियाणा के अर्ध-शुष्क पारिस्थितिकी तंत्र की एक खंडित आबादी का क्षेत्रीय सर्वेक्षण सितंबर 2019 से अगस्त 2020 के बीच, सुबह से शाम, वर्षभर हर ऋतु में पाक्षिक रूप से किया। समूह के आकार (3 से 72) और वनस्पति पर आंकड़े एकत्रित करने के लिए स्कैन सैंपलिंग और क्वाड्रैट विधियों का उपयोग किया गया तथा दुश्य अवलोकन के आधार पर यह पाया कि कुष्ण मृग अध्ययन स्थल से प्रलेखित कुल 53 पौधों की प्रजातियों में से 25 परिवारों की 26 प्रजातियों को विभिन्न प्राथमिकताओं के साथ खाते हैं। जिनमें उच्च औषधीय और चिकित्सीय मूल्यों वाली कुछ पौधों की प्रजातियों को प्राथमिकता दी गई जैसे आर्टेमिसिया स्कोपरिया, कुकुमिस कॉलस, ज़िज़िफस जुजुबी और ज़िज़ीफस न्यूमुलेरिया अधिकांश शाकाहारी जीवों के विपरीत, कृष्ण मृग ने विषाक्त और औषधीय रूप से समृद्ध आक (कैलोट्रोपिस प्रोसेरा) का भी सेवन किया। हमारा सुझाव है कि जिन चिड़ियाघरों में काले हिरण है, वे इनके आहार में इन पसंदीदा जंगली पौधों की प्रजातियों को शामिल कर सकते हैं। समह गतिविधि प्रतिरूप का विश्लेषण प्रति घंटा, मासिक तथा ऋतु आधार और समय प्रतिशत में परिवर्तित कर किया गया। भोजन की उपलब्धता बड़े पैमाने पर प्रभावित करते हुए देखा गया, मॉनसून में समूह भोजन गतिविधि अधिकतम $(62 \%)$ और सर्दियों में न्यूनतम $(50 \%)$ इसके बाद विश्राम सर्दियों में अधिकतम $(21 \%)$ और मानसून में न्यूनतम $(12 \%)$, था। भोजन/चलने का अनुपात मानसून में अधिकतम (5.2) और सर्दियों में न्यूनतम (3.1) था, जो आसपास के खेत में समूह देखे जाने की संख्या (सर्दियों में अधिकतम और मानसून में न्यूनतम) के साथ सहसंबद्ध था। जब जानवरों को प्राकृतिक आवास में भोजन की कमी का सामना करना पड़ता है तब वे फसलों को खाते हैं।

Author details: VIKRAM DELU, PRIYA and KIRAN are pursuing PhD at Department of Zoology \& Aquaculture, COBS\&H, CCS HAU Hisar under the supervision of DR. DHARAMBIR SINGH, Asstt. Professor in Zoology who has specialized in animal behavior, fish nutrition and ornithology. DR. SUMIT DOOKIA, Asstt. Professor, University School of Environment Management, GGSIP, Govt. of NCT of Delhi has specialized in wildlife sciences especially mammalian ecology of Thar Desert.

Author contributions: VD \& DS designed the research plan, DS guided the research. VD collected the field data and wrote draft of the manuscript. DS \& SD analyzed the data and finalize draft of the manuscript. SD added scientific inputs and also advised during research and writing period. Priya and Kiran helped in data collection and manuscript writing. 

Dr. John Noyes, Natural History Museum, London, UK

Dr. Albert G. Orr, Griffith University, Nathan, Australia

Dr. Sameer Padhye, Katholieke Universiteit Leuven, Belgium

Dr. Nancy van der Poorten, Toronto, Canada

Dr. Kareen Schnabel, NIWA, Wellington, New Zealand

Dr. R.M. Sharma, (Retd.) Scientist, Zoological Survey of India, Pune, India

Dr. Manju Siliwal, WILD, Coimbatore, Tamil Nadu, India

Dr. G.P. Sinha, Botanical Survey of India, Allahabad, India

Dr. K.A. Subramanian, Zoological Survey of India, New Alipore, Kolkata, India

Dr. P.M. Sureshan, Zoological Survey of India, Kozhikode, Kerala, India

Dr. R. Varatharajan, Manipur University, Imphal, Manipur, India

Dr. Eduard Vives, Museu de Ciències Naturals de Barcelona, Terrassa, Spain

Dr. James Young, Hong Kong Lepidopterists' Society, Hong Kong

Dr. R. Sundararaj, Institute of Wood Science \& Technology, Bengaluru, India

Dr. M. Nithyanandan, Environmental Department, La Ala Al Kuwait Real Estate. Co. K.S.C.,

Kuwait

Dr. Himender Bharti, Punjabi University, Punjab, India

Mr. Purnendu Roy, London, UK

Dr. Saito Motoki, The Butterfly Society of Japan, Tokyo, Japan

Dr. Sanjay Sondhi, TITLI TRUST, Kalpavriksh, Dehradun, India

Dr. Nguyen Thi Phuong Lien, Vietnam Academy of Science and Technology, Hanoi, Vietnam

Dr. Nitin Kulkarni, Tropical Research Institute, Jabalpur, India

Dr. Robin Wen Jiang Ngiam, National Parks Board, Singapore

Dr. Lional Monod, Natural History Museum of Geneva, Genève, Switzerland.

Dr. Asheesh Shivam, Nehru Gram Bharti University, Allahabad, India

Dr. Rosana Moreira da Rocha, Universidade Federal do Paraná, Curitiba, Brasi

Dr. Kurt R. Arnold, North Dakota State University, Saxony, Germany

Dr. James M. Carpenter, American Museum of Natural History, New York, USA

Dr. David M. Claborn, Missouri State University, Springfield, USA

Dr. Kareen Schnabel, Marine Biologist, Wellington, New Zealand

Dr. Amazonas Chagas Júnior, Universidade Federal de Mato Grosso, Cuiabá, Brasil

Mr. Monsoon Jyoti Gogoi, Assam University, Silchar, Assam, India

Dr. Heo Chong Chin, Universiti Teknologi MARA (UiTM), Selangor, Malaysia

Dr. R.J. Shiel, University of Adelaide, SA 5005, Australia

Dr. Siddharth Kulkarni, The George Washington University, Washington, USA

Dr. Priyadarsanan Dharma Rajan, ATREE, Bengaluru, India

Dr. Phil Alderslade, CSIRO Marine And Atmospheric Research, Hobart, Australia

Dr. John E.N. Veron, Coral Reef Research, Townsville, Australia

Dr. Daniel Whitmore, State Museum of Natural History Stuttgart, Rosenstein, Germany.

Dr. Yu-Feng Hsu, National Taiwan Normal University, Taipei City, Taiwan

Dr. Keith V. Wolfe, Antioch, California, USA

Dr. Siddharth Kulkarni, The Hormiga Lab, The George Washington University, Washington,

D.C., USA

Dr. Tomas Ditrich, Faculty of Education, University of South Bohemia in Ceske

Budejovice, Czech Republic

Dr. Mihaly Foldvari, Natural History Museum, University of Oslo, Norway

Dr. V.P. Uniyal, Wildlife Institute of India, Dehradun, Uttarakhand 248001, India

Dr. John T.D. Caleb, Zoological Survey of India, Kolkata, West Bengal, India

Dr. Priyadarsanan Dharma Rajan, Ashoka Trust for Research in Ecology and the Environment

(ATREE), Royal Enclave, Bangalore, Karnataka, India

\section{Fishes}

Dr. Neelesh Dahanukar, IISER, Pune, Maharashtra, India

Dr. Topiltzin Contreras MacBeath, Universidad Autónoma del estado de Morelos, México

Dr. Heok Hee Ng, National University of Singapore, Science Drive, Singapore

Dr. Rajeev Raghavan, St. Albert's College, Kochi, Kerala, India

Dr. Robert D. Sluka, Chiltern Gateway Project, A Rocha UK, Southall, Middlesex, UK

Dr. E. Vivekanandan, Central Marine Fisheries Research Institute, Chennai, India

Dr. Davor Zanella, University of Zagreb, Zagreb, Croatia

Dr. A. Biju Kumar, University of Kerala, Thiruvananthapuram, Kerala, India

Dr. Akhilesh K.V., ICAR-Central Marine Fisheries Research Institute, Mumbai Research

Centre, Mumbai, Maharashtra, India

Dr. J.A. Johnson, Wildlife Institute of India, Dehradun, Uttarakhand, India

Amphibians

Dr. Sushil K. Dutta, Indian Institute of Science, Bengaluru, Karnataka, India

Dr. Annemarie Ohler, Muséum national d'Histoire naturelle, Paris, France

\section{Reptiles}

Dr. Gernot Vogel, Heidelberg, Germany

Dr. Raju Vyas, Vadodara, Gujarat, India

Dr. Pritpal S. Soorae, Environment Agency, Abu Dubai, UAE.

Prof. Dr. Wayne J. Fuller, Near East University, Mersin, Turkey

Prof. Chandrashekher U. Rivonker, Goa University, Taleigao Plateau, Goa. India

Dr. S.R. Ganesh, Chennai Snake Park, Chennai, Tamil Nadu, India

Dr. Himansu Sekhar Das, Terrestrial \& Marine Biodiversity, Abu Dhabi, UAE
Birds

Dr. Hem Sagar Baral, Charles Sturt University, NSW Australia

Dr. Chris Bowden, Royal Society for the Protection of Birds, Sandy, UK

Dr. Priya Davidar, Pondicherry University, Kalapet, Puducherry, India

Dr. J.W. Duckworth, IUCN SSC, Bath, UK

Dr. Rajah Jayapal, SACON, Coimbatore, Tamil Nadu, India

Dr. Rajiv S. Kalsi, M.L.N. College, Yamuna Nagar, Haryana, India

Dr. V. Santharam, Rishi Valley Education Centre, Chittoor Dt., Andhra Pradesh, India

Dr. S. Balachandran, Bombay Natural History Society, Mumbai, India

Mr. J. Praveen, Bengaluru, India

Dr. C. Srinivasulu, Osmania University, Hyderabad, India

Dr. K.S. Gopi Sundar, International Crane Foundation, Baraboo, USA

Dr. Gombobaatar Sundev, Professor of Ornithology, Ulaanbaatar, Mongolia

Prof. Reuven Yosef, International Birding \& Research Centre, Eilat, Israel

Dr. Taej Mundkur, Wetlands International, Wageningen, The Netherlands

Dr. Carol Inskipp, Bishop Auckland Co., Durham, UK

Dr. Tim Inskipp, Bishop Auckland Co, Durham, UK

Dr. V. Gokula, National College, Tiruchirappalli, Tamil Nadu, India

Dr. Arkady Lelej, Russian Academy of Sciences, Vladivostok, Russia

Dr. Simon Dowell, Science Director, Chester Zoo, UK

Dr. Mário Gabriel Santiago dos Santos, Universidade de Trás-os-Montes e Alto Douro,

Quinta de Prados, Vila Real, Portugal

Dr. Grant Connette, Smithsonian Institution, Royal, VA, USA

Dr. M. Zafar-ul Islam, Prince Saud Al Faisal Wildlife Research Center, Taif, Saudi Arabia

Mammals

Dr. Giovanni Amori, CNR - Institute of Ecosystem Studies, Rome, Italy

Dr. Anwaruddin Chowdhury, Guwahati, India

Dr. David Mallon, Zoological Society of London, UK

Dr. Shomita Mukherjee, SACON, Coimbatore, Tamil Nadu, India

Dr. Angie Appel, Wild Cat Network, Germany

Dr. P.O. Nameer, Kerala Agricultural University, Thrissur, Kerala, India

Dr. Ian Redmond, UNEP Convention on Migratory Species, Lansdown, UK

Dr. Heidi S. Riddle, Riddle's Elephant and Wildlife Sanctuary, Arkansas, USA

Dr. Karin Schwartz, George Mason University, Fairfax, Virginia.

Dr. Lala A.K. Singh, Bhubaneswar, Orissa, India

Dr. Mewa Singh, Mysore University, Mysore, India

Dr. Paul Racey, University of Exeter, Devon, UK

Dr. Honnavalli N. Kumara, SACON, Anaikatty P.O., Coimbatore, Tamil Nadu, India

Dr. Nishith Dharaiya, HNG University, Patan, Gujarat, India

Dr. Spartaco Gippoliti, Socio Onorario Società Italiana per la Storia della Fauna "Giuseppe

Altobello", Rome, Italy

Dr. Justus Joshua, Green Future Foundation, Tiruchirapalli, Tamil Nadu, India

Dr. H. Raghuram, The American College, Madurai, Tamil Nadu, India

Dr. Paul Bates, Harison Institute, Kent, UK

Dr. Jim Sanderson, Small Wild Cat Conservation Foundation, Hartford, USA

Dr. Dan Challender, University of Kent, Canterbury, UK

Dr. David Mallon, Manchester Metropolitan University, Derbyshire, UK

Dr. Brian L. Cypher, California State University-Stanislaus, Bakersfield, CA

Dr. S.S. Talmale, Zoological Survey of India, Pune, Maharashtra, India

Prof. Karan Bahadur Shah, Budhanilakantha Municipality, Kathmandu, Nepal

Dr. Susan Cheyne, Borneo Nature Foundation International, Palangkaraja, Indonesia

Dr. Hemanta Kafley, Wildlife Sciences, Tarleton State University, Texas, USA

\section{Other Disciplines}

Dr. Aniruddha Belsare, Columbia MO 65203, USA (Veterinary)

Dr. Mandar S. Paingankar, University of Pune, Pune, Maharashtra, India (Molecular)

Dr. Jack Tordoff, Critical Ecosystem Partnership Fund, Arlington, USA (Communities)

Dr. Ulrike Streicher, University of Oregon, Eugene, USA (Veterinary)

Dr. Hari Balasubramanian, EcoAdvisors, Nova Scotia, Canada (Communities)

Dr. Rayanna Hellem Santos Bezerra, Universidade Federal de Sergipe, São Cristóvão, Brazil

Dr. Jamie R. Wood, Landcare Research, Canterbury, New Zealand

Dr. Wendy Collinson-Jonker, Endangered Wildlife Trust, Gauteng, South Africa

Dr. Rajeshkumar G. Jani, Anand Agricultural University, Anand, Gujarat, India

Dr. O.N. Tiwari, Senior Scientist, ICAR-Indian Agricultural Research Institute (IARI), New

Delhi, India

Dr. L.D. Singla, Guru Angad Dev Veterinary and Animal Sciences University, Ludhiana, India

Dr. Rupika S. Rajakaruna, University of Peradeniya, Peradeniya, Sri Lanka

Dr. Bahar Baviskar, Wild-CER, Nagpur, Maharashtra 440013, India

Reviewers 2018-2020

Due to pausity of space, the list of reviewers for $2018-2020$ is available online.

The opinions expressed by the authors do not reflect the views of the Journal of Threatened Taxa, Wildlife Information Liaison Development Society, Zoo Outreach Organization, or any of the partners. The journal, the publisher, the host, and the partners are not responsible for the accuracy of the political boundaries shown in the maps by the authors.

Journal of Threatened Taxa is indexed/abstracted in Bibliography of Systematic Mycology, Biological Abstracts, BIOSIS Previews, CAB Abstracts, EBSCO, Google Scholar, Index Copernicus, Index Fungorum, JournalSeek, National Academy of Agricultural Sciences, NewJour, OCLC WorldCat, SCOPUS, Stanford University Libraries, Virtual Library of Biology, Zoological Records.

NAAS rating (India) 5.64
Print copies of the Journal are available at cost. Write to:

The Managing Editor, JoTT,

c/o Wildlife Information Liaison Development Society,

No. 12, Thiruvannamalai Nagar, Saravanampatti - Kalapatti Road,

Saravanampatti, Coimbatore, Tamil Nadu 641035, India

ravi@threatenedtaxa.org 


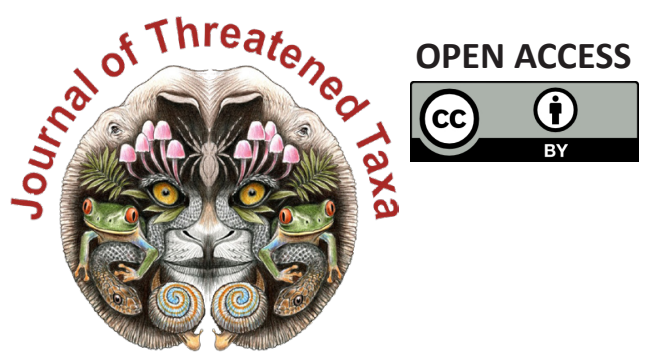

www.threatenedtaxa.org

The Journal of Threatened Taxa (JoTT) is dedicated to building evidence for conservation globally by publishing peer-reviewed articles online every month at a reasonably rapid rate at www.threatenedtaxa.org. All articles published in JoTT are registered under Creative Commons Attribution 4.0 International License unless otherwise mentioned. JoTT allows allows unrestricted use, reproduction, and distribution of articles in any medium by providing adequate credit to the author(s) and the source of publication.

ISSN 0974-7907 (Online) I ISSN $0974-7893$ (Print)

\section{November 2021 | Vol. 13 | No. 13 | Pages: 19887-20142 \\ Date of Publication: 26 November 2021 (Online \& Print) DOI: 10.11609/jott.2021.13.13.19887-20142}

\section{Article}

An inventory of geometrid moths (Lepidoptera: Geometroidea: Geometridae) of KalakadMundanthurai Tiger Reserve, India

- Geetha Iyer, Dieter Stüning \& Sanjay Sondhi, Pp. 19887-19920

\section{Communications}

Roadkills of Lowland Tapir Tapirus terrestris (Mammalia: Perissodactyla: Tapiridae) in one of its last refuges in the Atlantic Forest

- Aureo Banhos, Andressa Gatti, Marcelo Renan de Deus Santos, Leonardo Merçon,

Ilka Westermeyer, Natália Carneiro Ardente, Luis Francisco Oliveira Pereira Gonzaga, Lucas Mendes Barreto, Lucas Damásio, Tomas Lima Rocha, Vitor Roberto Schettino, Renata Valls, Helena Godoy Bergallo, Marcos Vinicius Freitas Silva, Athelson Stefanon Bittencourt, Danielle de Oliveira Moreira \& Ana Carolina Srbek-Araujo, Pp. 19921-19929

Scientific contributions and learning experiences of citizen volunteers with a small cat project in Sanjay Gandhi National Park, Mumbai, India

- Shomita Mukherjee, R. Nandini, P.V. Karunakaran \& Nayan Khanolkar, Pp. 19930-19936

Seasonal food preferences and group activity pattern of Blackbuck Antilope cervicapra (L., 1758) (Mammalia: Cetartiodactyla: Bovidae) in a semi-arid region of western Haryana, India

- Vikram Delu, Dharambir Singh, Sumit Dookia, Priya \& Kiran, Pp. 19937-19947

Studies on the habitats of Grey Francolin Francolinus pondicerianus (J.F. Gmelin, 1789) (Galliformes: Phasianidae) in northern districts of Tamil Nadu, India

- M. Pandian, Pp. 19948-19955

Recovery of vulture population in roosting and scavenging areas of Bastar and Bijapur, Chhattisgarh, India

- Sushil Kumar Dutta, Muntaz Khan, P.R.S. Nagi, Santosh Durgam \& Surabhi Dutta, Pp. 19956-19963

A geographical assessment of Chariganga and Arpara Beel (wetlands) of Nadia, West Bengal as a habitat of wetland birds

- Mehedi Hasan Mandal, Arindam Roy \& Giyasuddin Siddique, Pp. 19964-19975

Phenotypic plasticity in Barilius vagra (Hamilton, 1822) (Teleostei: Danionidae) from two geographically distinct river basins of Indian Himalaya

- Sumit Kumar, Sharali Sharma \& Deepak Singh, Pp. 19976-19984

Taxonomic notes, a new species, and a key to Indian species of the click beetle genus Cryptalaus Ôhira, 1967 (Coleoptera: Elateridae: Agrypninae)

- Harshad Parekar \& Amol Patwardhan, Pp. 19985-19999

Niche overlap of benthic macrofauna in a tropical estuary: diurnal variation

- Mário Herculano de Oliveira, Lidiane Gomes de Lima, Caroline Stefani da Silva Lima, Jéssica de Oliveira Lima Gomes, Franciely Ferreira Paiva, Graciele de Barros, Carlinda Railly Medeiros \& Joseline Molozzi, Pp. 20000-20010

Diversity of aquatic insects and biomonitoring of water quality in the upper Ganga River, a Ramsar site: a preliminary assessment

- Kritish De, Arkojyoti Sarkar, Kritika Singh, Virendra Prasad Uniyal, Jeyaraj Antony Johnson \& Syed Ainul Hussain, Pp. 20011-20018

Patterns of forest cover loss in the terrestrial Key Biodiversity Areas in the Philippines: critical habitat conservation priorities

- Bernard Peter O. Daipan, Pp. 20019-20032

The woody flora of Shettihalli Wildlife Sanctuary, central Western Ghats of Karnataka, India - A checklist

- Kanda Naveen Babu, Kurian Ayushi, Vincy K. Wilson, Narayanan Ayyappan \&

Narayanaswamy Parthasarathy, Pp. 20033-20055

Reproductive biology of Ophiorrhiza caudata C.E.C.Fisch. (Rubiaceae), an endemic and endangered creeping perennial herb of the Western Ghats, India

- Maria Theresa, Appukuttan Kamalabai Sreekala \& Jayalakshmi Mohanlal, Pp. 20056-20065
Short Communications

Successful rescue, medical management, rehabilitation, and translocation of a Red Panda Ailurus fulgens (Mammalia: Carnivora: Ailuridae) in Arunachal Pradesh, India - Jahan Ahmed, Sorang Tadap, Millo Tasser, Koj Rinya, Nekibuddin Ahmed \& Sunil Kyarong, Pp. 20066-20071

A rare photographic record of Eurasian Otter Lutra lutra with a note on its habitat from the Bhagirathi Basin, western Himalaya, India

- Ranjana Pal, Aashna Sharma, Vineet Kumar Dubey, Tapajit Bhattacharya, Jeyaraj Antony Johnson, Kuppusamy Sivakumar \& Sambandam Sathyakumar, Pp. 20072-20077

The first record of Medog Gliding Frog Rhacophorus translineatus Wu, 1977 (Anura: Rhacophoridae) from Chhukha District, Bhutan

- Sonam Lhendup \& Bal Krishna Koirala, Pp. 20078-20083

First record of a freshwater crab, Maydelliathelphusa masoniana (Henderson, 1893) (Decapoda: Brachyura: Gecarcinucidae) from West Bengal, India

- Ram Krishna Das, Pp. 20084-20089

Butterflies of Amrabad Tiger Reserve, Telangana, India

- Deepa Jaiswal, B. Bharath, M. Karuthapandi, Shrikant Jadhav, S. Prabakaran \& S. Rehanuma Sulthana, Pp. 20090-20097

An enumeration of the flowering plants of Kyongnosla Alpine Sanctuary in eastern Sikkim, India

- Sudhansu Sekhar Dash, Subhajit Lahiri \& Ashiho Asoshii Mao, Pp. 20098-20117

A new record of psychrotrophic Paecilomyces formosus (Eurotiales: Ascomycota) from India: morphological and molecular characterization

- Skarma Nonzom \& Geeta Sumbali, Pp. 20118-20123

Notes

Study on incidence and pathology of gastrointestinal parasitic infections in Nilgai Boselaphus tragocamelus in Hisar, Haryana, India

- Maneesh Sharma, B.L. Jangir, D. Lather, G.A. Chandratre, V. Nehra, K.K. Jakhar \& G. Narang, Pp. 20124-20127

An unusual vocalization of Brown Hawk-Owl Ninox scutulata (Raffles, 1822) (Aves:

Strigiformes: Strigidae) recorded from Kerala, India

- Riju P. Nair \& Shine Raj Tholkudiyil, Pp. 20128-20129

New distribution data on the genus Maripanthus Maddison, 2020 (Araneae: Salticidae) from southern India

- A. Asima, John T.D. Caleb, Dhruv A. Prajapati \& G. Prasad, Pp. 20130-20132

On the IUCN status of Boesenbergia albolutea and B. rubrolutea (Zingiberaceae) and typification of $B$. rubrolutea

- K. Aishwarya \& M. Sabu, Pp. 20133-20135

New records of mass seeding Cephalostachyum latifolium Munro (Poaceae) along the midelevation broadleaved forest of Sarpang district, Bhutan

- Jigme Tenzin, Sangay Nidup \& Dago Dorji, Pp. 20136-20139

Response

If habitat heterogeneity is effective for conservation of butterflies in urban landscapes of Delhi, India?' Unethical publication based on data manipulation

- Sanjay Keshari Das \& Rita Singh, Pp. 20140-20142

Publisher \& Host
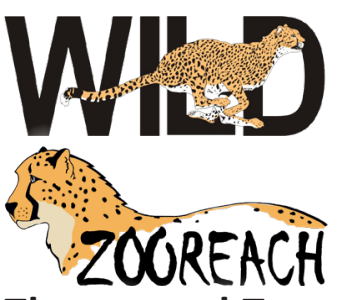

Threatened Taxa 